\title{
Agronomic performance and drought tolerance level of sweet potato hybrids grown in Kupang, East Nusa Tenggara, Indonesia
}

\author{
YOSEP S. MAU`, ANTONIUS S.S. NDIWA, JENNY E.R. MARKUS, I G.B. ADWITA ARSA \\ Faculty of Agriculture, Universitas Nusa Cendana. Jl. Adisucipto, Penfui, Kupang 85001, East Nusa Tenggara, Indonesia. \\ Tel./fax.: +62-380-881085, `email:yosepmau@yahoo.com
}

Manuscript received: 1 July 2019. Revision accepted: 17 July 2019.

\begin{abstract}
Mau YS, Ndiwa ASS, Markus JER, Arsa IGBA. 2019. Agronomic performance and drought tolerance level of sweet potato hybrids grown in Kupang, East Nusa Tenggara, Indonesia. Biodiversitas 20: 2187-2196. This study was conducted to evaluate agronomic performance and to assess drought tolerance level of purple and orange-fleshed $\mathrm{F}_{1}$ sweet potato hybrids in dryland during dry season in Kupang, East Nusa Tenggara. The study was carried out in Integrated Archipelagic Dryland Field Laboratory of Universitas Nusa Cendana, Kupang, from May to October 2018. Two sets of experiment were conducted, the first was for evaluation of agronomic performance, and the second was for evaluation of drought tolerance of the sweet potato genotypes. The first experiment asses sed the agronomic performance of 20 sweet potato genotypes in a Randomized Block Design. The second experiment employed a Split Plot Design consisted of irrigation level as the main plot and sweet potato genotypes as subplot treatments. The main plot consisted of no stress (normal) and water-stressed conditions while the sub-plot comprised of 20 genotypes of the sweet potato. The observed agronomic performance variables included growth and yield parameters. Tuber yields in no stress and water-stressed conditions were observed and used for assessment of drought tolerance. The results showed that, in the agronomic performance experiment, the sweet potato genotypes differed significantly in all the observed agronomic performance variables including growth, yield contributing, and yield variables. UNC2016.Cil/JPV.01 and UNC2016.Cil/JPV.05 were short maturing genotypes with only about 90 days to harvesting while the rest of the genotypes were harvested in 120 to 150 days. The genotypes were also significantly varied in tuber yield; the highest was observed in UNC2016.JPV/KDL.11 (43.38 t ha-1). In the drought tolerance evaluation experiment, tuber yields in no stress and stressed condition were, respectively, $23.42 \mathrm{t} \mathrm{ha}^{-1}$ and $7.08 \mathrm{t} \mathrm{ha}^{-1}$. Six $\mathrm{F}_{1}$ hybrids were classified and selected as drought-tolerant genotypes with high yielding performance in both no stress and water-stressed conditions.
\end{abstract}

Keywords: Agronomic performance, drought tolerance, hybrids, sweet potato

\section{INTRODUCTION}

Sweet potato [Ipomoea batatas L. (Lam)] is the second most important tuber crop in Indonesia. In addition to its function as food source, sweet potatoes are also used as feed and industrial raw materials. Carbohydrate content of sweet potato is high so that it has the potential to be used as a staple food source besides rice and corn. Sweet potato is also rich in minerals, vitamins and antioxidants that are important for human health (Rabah et al. 2004; Husna et al. 2013; Ginting et al. 2015). Toda date, however, sweet potato has not been used to meet its full potential in Indonesia, where rice is still the most prominent staple food for most of the population.

In the dryland-dominated province of East Nusa Tenggara (Nusa Tenggara Timur/NTT Province), sweet potato is one of the major commodities that has been traditionally cultivated by farmers and used as a staple food source for rice and corn substitute. However, the use of sweet potato as the primary food source in the region is still left behind that of rice and maize. Low productivity and quality, as well as poor postharvest handling and processing of sweet potato at the farmer level, are vital factors determining underutilization of this crop as the main staple food alternative in this province.

The low yield and quality of sweet potato are caused by many factors, including the poor cultivation techniques, sub-optimal cropping areas, pest and disease infestations, and the low yielding ability of cultivated sweet potato genotypes. The last two factors can be overcome by the production of high yielding and pest and disease-resistant varieties employing local germplasm. East Nusa Tenggara (NTT) Province is rich in sweet potato germplasm that can serve as gene source for the selection of desirable traits and also as the parental source in crossing program for the production of superior genotypes.

Several local sweet potato clones from NTT Province have been studied in recent years, some of which showed desirable characters such as moderately tolerant to drought (Mau 2011), moderate and stable yield across diverse environments (Mau et al. 2013), moderately resistant to sweet potato weevil (Mau et al. 2011), and resistant to scab disease (Mau 2018). Despite the observed desirable traits possessed by the local sweet potato clones, there are still many limitations that need to be improved such as moderate yielding ability, low nutritional value, especially beta carotene and anthocyanin content, and lack of resistance to sweet potato weevil. Improvements of these traits can be achieved through crossing the local clones with superior genotypes to produce superior varieties with multiple desirable traits. Improved sweet potato varieties with desirable attributes such as high tuber yield and 
drought tolerant are urgently needed in regions with suboptimal growing conditions such as NTT Province since low yielding cultivated varieties, and drought stress are the most dominant factors causing low sweet potato yield in this region.

Several $F_{1}$ hybrid populations of sweet potato had been produced from crosses involving locally adapted clone NPL-01 and SBD-04 (Mau et al. 2013; Mau et al. 2016) and Indonesian released varieties Cilembu, Kidal, and Papua Solossa (BALITKABI 2016), as well as an introduction variety JPV. The results showed that some of the $F_{1}$ populations were able to produce tubers with varying flesh colors, i.e., white, yellow, orange, and purple (Mau et al. 2016). Orange-fleshed sweet potatoes are the primary sources of beta-carotene or pro-vitamin A (Oki et al. 2006; Teow et al. 2007; Rose and Vasanthakaalam 2011; Rahman et al. 2013) while the purple-fleshed ones are rich in antioxidants (anthocyanin) (Teow et al. 2007; Husna et al. 2013; Ji et al. 2015) which possess health-promoting properties such as anti-cancer (Saigusa et al. 2005; Kurata et al. 2007; Lim et al. 2013), anti-inflammatory (Zhang et al. 2009; Wang et al. 2010), anti-aging (Jang et al. 2005), anti-hypertension (Kobayashi et al. 2005).

The orange and purple-fleshed $F_{1}$ populations producing fresh tuber weight of $\geq 0.5 \mathrm{~kg}$ per plant in the greenhouse/ pod condition and unreplicated plots had been selected and subjected to further evaluation to identify superior genotypes having desirable agronomic traits. This study aimed to (i) elucidate agronomic performance of the selected $F_{1}$ populations in replicated plots in the field, (ii) assess drought tolerance level of the $F_{1}$ populations. Genotypes showing superior agronomic performance and drought tolerance will be further evaluated in multi-environment to be prepared as candidates for varietal release.

\section{MATERIALS AND METHODS}

\section{Experimental site and plant materials}

This research was carried out in the Archipelagic Dryland Field Laboratory of Universitas Nusa Cendana,
Kupang, Indonesia $\left(10.15452^{\circ} \mathrm{S}\right.$ and $123.66993^{\circ} \mathrm{E}, 110 \mathrm{~m}$ asl.) from May to October 2018. The climatic conditions during the field experiment are presented in Table 1. The soil type of the research site was an Entisol.

Twenty sweet potato genotypes were evaluated, 16 of which were $F_{1}$ hybrid populations and four of which were Indonesian released varieties (check varieties) kindly provided by Indonesian Legumes and Tuber Crops Research Institute (ILETRI/BALITKABI), Malang, East Java, Indonesia. These four varieties were selected as check varieties as they are among the most recently released Indonesian orange-fleshed and purple-fleshed sweet potato varieties and also have been cultivated in East Nusa Tenggara Province. Details of the sweet potato genotypes evaluated are presented in Table 2.

Table 2. Sweet potato genotypes evaluated for agronomic performance and drought tolerance

\begin{tabular}{lll}
\hline \multicolumn{1}{c}{ Genotype code } & Flesh color & $\begin{array}{c}\text { Origin of } \\
\text { population }\end{array}$ \\
\hline UNC2016.CIL/JPV.01 & Purple & F1 Population \\
UNC2016.CIL/JPV.02 & Light purple & F1 Population \\
UNC2016.CIL/JPV.04 & Light purple & F1 Population \\
UNC2016.CIL/JPV.05 & Purple & F1 Population \\
UNC2016.KDL/NPL.02 & Purple & F1 Population \\
UNC2016.JPV/KDL.08 & Light orange & F1 Population \\
UNC2016.JPV/KDL.11 & Pale orange & F1 Population \\
UNC2016.JPV/KDL.02 & Light purple & F1 Population \\
UNC2016.NPL/JPV//KDL.02 & Orange & F1 Population \\
UNC2016.NPL/KDL.02 & Orange & F1 Population \\
UNC2016.KDL/NPL.01 & Orange & F1 Population \\
UNC2016.NPL/PSOL.16 & Purple & F1 Population \\
UNC2016.NPL/SBD.04.1 & Light orange & F1 Population \\
UNC2016.JPV/KDL//NPL.04 & Purple & F1 Population \\
UNC2016.PSOL/NPL.15 & Orange & F1 Population \\
UNC2016.KDL/V1-CIL.01 & Light orange & F1 Population \\
ANTIN-1 & Purple & ILETRI \\
ANTIN-2 & Purple & ILETRI \\
BETA-1 & Orange & ILETRI \\
BETA-2 & Orange & ILETRI \\
\hline
\end{tabular}

Note: ILETRI $=$ Indonesian released variety

Table 1. Climatic conditions during the field experiment (May-October 2018)

\begin{tabular}{lcccccc}
\hline Month & Rainfall $(\mathbf{m m})$ & $\begin{array}{c}\text { Number of } \\
\text { Rainy days }\end{array}$ & \multicolumn{3}{c}{ Temperature $\left({ }^{\circ} \mathbf{C}\right)$} & Humidity $(\%)$ \\
\cline { 4 - 5 } & & 0 & 24.5 & Max. & Mean & \\
\hline May & 0 & 1 & 22.8 & 32.2 & 28.1 & 70 \\
June & 2 & 0 & 22.0 & 32.5 & 27.2 & 70 \\
July & 0 & 2 & 22.1 & 32.1 & 26.4 & 70 \\
August & 4 & 1 & 21.7 & 33.2 & 27.3 & 71 \\
September & 0.5 & 0 & 23.0 & 33.0 & 28.0 & 70 \\
October & 0 & & & &
\end{tabular}

Source: Stasiun Klimatologi Kupang. 


\section{Experimental design}

Two experimental sets were conducted in the field, one for evaluation of agronomic performance and the other was for evaluation of drought tolerance of the tested sweet potato genotypes. A Randomized Block Design was employed in the agronomic performance evaluation, and a Split Plot Design was used for assessment of the drought tolerance. The Randomized Block Design comprised of 20 sweet potato genotypes as treatment; each was two replicates with a total of 40 plots. Meanwhile, the Split-Plot Design comprised of irrigation level as the main plot and sweet potato genotype as the sub-plot treatments. Two irrigation levels were assigned in the main-plot, i.e., $\mathrm{I}_{0}$ for no water stress/normal condition and $I_{1}$ for the waterstressed condition. In the $\mathrm{I}_{0}$, the plants were irrigated daily to maintain field capacity level while in the $I_{1}$ the plants were irrigated only once in 10 days to impose the waterstressed condition. The sub-plot treatment consisted of 20 sweet potato genotypes, similar to those used in the agronomic performance evaluation experiment. The treatments in the Split-Plot Design experimental set consisted of two replicates with a total of 80 experimental units were elucidated.

\section{Field preparation and planting of the sweet potato genotypes}

The experimental field was initially cleared from weeds and then plowed at $30 \mathrm{~cm}$ depth, cleaned from plant debris, and grazed. The planting plot of $3 \mathrm{~m} \mathrm{x} 1.4 \mathrm{~m}\left(4.2 \mathrm{~m}^{2}\right)$ size was prepared for each experimental unit in both experimental sets two weeks before planting. Betweenblock spacing was $100 \mathrm{~cm}$ while between-main plot spacing and sub-plot spacing was each $50 \mathrm{~cm}$. Cow manure was applied to each planting plot at a dosage of $2.1 \mathrm{~kg} \mathrm{plot}^{-}$ ${ }^{1}$ or equivalent to $5 \mathrm{t} \mathrm{ha}^{-1}$ at one week before planting. A basal compound fertilizer (NPK: 16:16:16) was applied at the time of planting at a dose of $126 \mathrm{~g} \mathrm{plot}^{-1}$, equivalent to $300 \mathrm{~kg} \mathrm{ha}^{-1}$.

Planting materials used in the study were sweet potato cuttings of about $30-40 \mathrm{~cm}$ in length/4-6 nodes each. The cuttings were obtained from two months old sweet potato plants of each genotype evaluated. The cuttings were planted in the plots with a plant spacing of $65 \mathrm{~cm}$ between rows and $50 \mathrm{~cm}$ within the row; each planting hole was planted with one cutting. The planting was done by inserting one-third/2-3 nodes of the lower part of the cutting into the planting hole, and the remaining two-thirds of the cutting was left above the ground. The plants were maintained according to the standard sweet potato cultivation techniques including weeding, irrigation, fertilization, and pest and disease control.

\section{Irrigation of sweet potato plants}

In the agronomic performance evaluation experiment, irrigation was provided daily while in the drought tolerance evaluation the plants were watered according to the assigned treatment of two irrigation levels, i.e., nonstressed condition (irrigation was provided daily) and water-stressed condition (irrigation was provided once in ten days). Irrigation was done to reach field capacity level by considering the amount of water loss through evapotranspiration based on the assumed reference evapotranspiration $\left(\mathrm{Et}_{0}\right)$ value in Kupang during the dry season (May-October), i.e., 5.22-5.27 $\mathrm{mm}$ per day and the mid-season sweet potato plant coefficient of 1.15 (Brouwer and Herbloem 1986).

\section{Observation and data analysis}

In the agronomic performance evaluation experiment, observation was done on growth, yield contributing, and yield variables. The growth variables were observed at 90 days after planting included vine length, number of leaves per plant, and number of secondary branches per plant, while yield contributing and yield variables (recorded at harvest) included harvesting date, tuber number per plant, tuber length, tuber diameter, harvest index, and marketable tuber $(\geq 100 \mathrm{~g})$ yield plot $^{-1}$. The observed variables were subjected to one-way ANOVA, followed by post hoc Duncan Multiple Range Test (0.05) for separation of the treatment means.

The main variable observed in the drought tolerance evaluation experiment was fresh tuber yield plot $^{-1}$ under both no water stress and water-stressed conditions. Mean tuber yields $\left(\mathrm{kg} \mathrm{ha}^{-1}\right)$ under both conditions were used to determine the drought tolerance level of tested sweet potato genotypes based on the calculated drought tolerance indices previously employed by various studies. The indices included MP (mean performance), STI (stress tolerance index), and SSI (stress susceptibility index) (Bidinger et al. 1978; Fischer and Maurer 1978; Mau et al. 2011, 2014), GMP (geometric mean performance), MRP (mean relative performance), HARM (harmonic yield), YSI (yield stress index), REI (relative expression index), and SNPI= Stress non-stress production index (Farshadfar and Sutka 2002; Moosavi et al. 2008; Farshadfar and Elyasi 2012; Ali et al. 2013; Mau et al. 2019).

\section{RESULTS AND DISCUSSION}

\section{Growth variables}

The tested sweet potato genotypes showed large differences in the observed growth variables (Table 3). Vine length varied considerably from $55.7 \mathrm{~cm}$ (BETA-2) to $149 \mathrm{~cm}$ (UNC2016.PSOL/NPL.15) while leaf number per plant ranged from 160 (UNC2016.KDL/V1.CIL.01) to 368 (UNC2016.JPV/KDL.11). Most of the clones had a short to moderate vine length, much shorter than those observed in orange-fleshed sweet potato $(117.3-253.3 \mathrm{~cm})$ reported by Rahman et al. (2013) and local sweet potatoes from NTT Province (115.9-216.4 cm) (Mau et al. 2013). In contrast to vine length, leaf number per plant of the present study (160.3-366.5) was much higher (about three folds) than that observed in the local sweet potato from NTT Province $(50.8-127.3 \mathrm{~cm})$ (Mau et al. 2013). A much wider range of vine length $(90.3-283.8 \mathrm{~cm})$ was reported in germplasm collection of Indonesian Legumes and Tuber Crops Research Institute/ILETRI (Rahajeng and Rahayuningsih 2017a). In addition to genetic differences among the sweet potato genotypes, differences in vine length and leaf 
number per plant between the present study and the previous studies may have also been caused by differences in environmental conditions where the sweet potato genotypes were grown.

Secondary branch number per plant was also recorded to largely differ among sweet potato clones. The $\mathrm{F}_{1}$ clones UNC2016.Cil/JPV.04 and UNC2016.KDL/V1.CIL.01, respectively, showed the highest and the lowest number of secondary branches per plant, ranging from 5.7 to 11.5 branches per plant. Number of secondary branches per plant of the current study was not substantially different from that in orange-fleshed sweet potato observed by Rahman et al. (2013) but the range was much wider than that found in local sweet potato of NTT Province (5-6 branches per plant) (Mau et al. 2013) and the ILETRI germplasm collection (0.3-1.5 branches per plant) (Rahajeng and Rahayuningsih 2017a). The wider range of secondary branches per plant of the present study may indicate that the sweet potato genotypes evaluated possess a higher genetic diversity of the trait.

Harvesting date substantially varied among tested sweet potato clones, ranging from 93 days to 152 days after planting. Harvesting dates of the orange-fleshed and most of the purple-fleshed sweet potato genotypes were almost similar to those of Indonesian released varieties (4-5 months) (BALITKABI 2016), however, it is interesting to observe in the present study that two purple-fleshed genotypes (UNC2016.CIL/JPV.01 and UNC2016.CIL/JPV.05) had a short harvesting date of only about three months. Short maturing genotypes are more favored in the regions with a short rainy season. Thus, these two genotypes are most suitable to be grown in areas with a short rainy season and rainfall-dependent region such as NTT Province, Indonesia.

\section{Yield component and yield variables}

Means and ANOVA results of yield component and yield variables are presented in Table 4 . Tuber number per plant was highly significantly varied $(\mathrm{P}<.01)$ among the genotypes, ranging from 1.50 to 5.5 tubers per plant; the highest was observed in the orange-fleshed $F_{1}$ clone UNC2016.JPV/KDL.11 while the lowest was in the three check varieties (Antin-1, Antin-2, Beta-2) and the orangefleshed $F_{1}$ clone UNC2016.NPL/KDL.02. Tuber number per plant of this study was much higher than that of orangefleshed sweet potato (OFSP) varieties (0.8-2.3 tubers per plant) observed by Mbusa et al. (2018) but much lower than that (5.1-14.9 tuber per plant) recorded in local sweet potato clones from NTT Province (Mau et al. 2013). Richardson (2009) reported almost similar tuber number plant $^{-1}$ as that of the current study.

Table 3. Mean vine length, number of leaves per plant, number of secondary branches per plant, and days to harvesting of tested sweet potato genotypes

\begin{tabular}{|c|c|c|c|c|c|c|c|c|}
\hline \multirow{2}{*}{$\begin{array}{l}\text { Sweet potato genotype } \\
\text { UNC2016.CIL/JPV.01 }\end{array}$} & \multicolumn{2}{|c|}{ Vine length $(\mathrm{cm})$} & \multicolumn{2}{|c|}{$\begin{array}{c}\text { \# of leaves per } \\
\text { plant }\end{array}$} & \multicolumn{2}{|c|}{$\begin{array}{c}\text { \# of secondary } \\
\text { branches per plant }\end{array}$} & \multicolumn{2}{|c|}{$\begin{array}{c}\text { Days to harvesting } \\
\text { (Day) }\end{array}$} \\
\hline & 87.2 & bcd & 195.7 & $\mathrm{ab}$ & 6.3 & $\mathrm{a}$ & 93.3 & $\mathrm{a}$ \\
\hline UNC2016.CIL/JPV.02 & 111.3 & def & 366.5 & $\mathrm{~h}$ & 6.8 & a & 139.3 & $\mathrm{c}$ \\
\hline UNC2016.CIL/JPV.04 & 95.5 & cde & 261.8 & de & 11.5 & $\mathrm{c}$ & 138.7 & $\mathrm{c}$ \\
\hline UNC2016.CIL/JPV.05 & 105.2 & def & 278.0 & def & 8.3 & $a b$ & 93.7 & $\mathrm{a}$ \\
\hline UNC2016.KDL/NPL.02 & 135.2 & fgh & 215.0 & $\mathrm{bc}$ & 7.0 & $a b$ & 125.6 & $\mathrm{~b}$ \\
\hline UNC2016.JPV/KDL.08 & 128.3 & fgh & 307.5 & ef & 4.5 & $\mathrm{a}$ & 124.3 & $\mathrm{~b}$ \\
\hline UNC2016.JPV/KDL.11 & 135.5 & fgh & 367.5 & $\mathrm{~h}$ & 8.2 & $\mathrm{~b}$ & 123.2 & $\mathrm{~b}$ \\
\hline UNC2016.JPV/KDL.02 & 123.5 & efgh & 317.6 & fg & 6.5 & $\mathrm{a}$ & 124.5 & $\mathrm{~b}$ \\
\hline UNC2016.NPL/JPV//KDL.02 & 143.0 & $\mathrm{gh}$ & 276.8 & def & 8.5 & $\mathrm{~b}$ & 134.6 & $\mathrm{bc}$ \\
\hline UNC2016.NPL/KDL.02 & 160.5 & $a b$ & 295.0 & ef & 7.7 & $\mathrm{~b}$ & 152.5 & $\mathrm{~d}$ \\
\hline UNC2016.KDL/NPL.01 & 111.5 & def & 245.8 & $\mathrm{~cd}$ & 7.2 & $a b$ & 136.8 & $\mathrm{c}$ \\
\hline UNC2016.NPL/PSOL.16 & 103.0 & def & 363.7 & $\mathrm{~h}$ & 5.8 & a & 134.7 & $\mathrm{bc}$ \\
\hline UNC2016.NPL/SBD.04.1 & 106.5 & def & 301.4 & ef & 8.2 & $\mathrm{~b}$ & 143.5 & $\mathrm{c}$ \\
\hline UNC2016.JPV/KDL//NPL.04 & 118.0 & defg & 161.8 & $\mathrm{a}$ & 8.5 & $\mathrm{~b}$ & 136.3 & $\mathrm{c}$ \\
\hline UNC2016.PSOL/NPL.15 & 149.0 & $\mathrm{~h}$ & 268.2 & de & 8.5 & $\mathrm{~b}$ & 142.4 & $\mathrm{c}$ \\
\hline UNC2016.KDL/V1-CIL.01 & 67.3 & $a b c$ & 160.3 & $\mathrm{a}$ & 5.7 & a & 125.8 & $\mathrm{~b}$ \\
\hline ANTIN-1 & 104.0 & def & 214.5 & $\mathrm{bc}$ & 9.8 & $\mathrm{~b}$ & 127.7 & $\mathrm{~b}$ \\
\hline ANTIN-2 & 116.0 & defg & 356.7 & $\mathrm{gh}$ & 10.3 & $\mathrm{bc}$ & 149.4 & $\mathrm{~d}$ \\
\hline BETA-1 & 87.8 & bcd & 197.8 & $a b$ & 8.50 & $\mathrm{~b}$ & 148.3 & $\mathrm{~d}$ \\
\hline BETA-2 & 55.7 & $\mathrm{a}$ & 206.0 & $\mathrm{bc}$ & 7.50 & $a b$ & 130.3 & $\mathrm{bc}$ \\
\hline Mean & 112.2 & & 276.9 & & 7.8 & & 131.2 & \\
\hline F-value & $8.06 * *$ & & $26.43 * *$ & & $6.41 *$ & & $215.15 * *$ & \\
\hline Coefficient of Variation & 12.10 & & 15.39 & & 9.39 & & 5.07 & \\
\hline
\end{tabular}

Note: ${ }^{* *}$ highly significant $(\mathrm{P}<01),{ }^{*}$ significant $(\mathrm{P}<0.05)$. Numbers within the same column followed by the same letter $(\mathrm{s})$ are not significantly different at 0.05 DMRT. 
Both tuber length and tuber diameter were highly significantly affected by the treatment of sweet potato genotypes. Tuber length ranged from $12.75 \mathrm{~cm}$ (UNC2016.PSOL/NPL.15) to $21.85 \quad \mathrm{~cm}$ (UNC2016.CIL/JPV.04) while tuber diameter ranged from $3.0 \mathrm{~cm}$ (UNC2016.CIL/JPV.04) to $7.25 \mathrm{~cm}$ (UNC2016.PSOL/NPL.15) (Table 4). Interestingly, the clone producing the longest tuber contrastingly produced the smallest tuber diameter, vice versa. All of these differences might be due to the differences in the genetic background of the tested sweet potato clones as they were all tested in the same environment. Tuber length of the present study was slightly different from that of ILETRI germplasm collection (5.5-18.15 cm) (Rahajeng and Rahayuningsih 2017a) and orange-fleshed sweet potato evaluated in Blitar and Mojokerot, East Java $(8-18 \mathrm{~cm})$ (Rahajeng and Rahayuningsih 2017b), but the tuber diameter was nearly in the same range as those of the previous studies (3.30-8.4 cm and 3.5-7.4 cm, respectively). Mau et al. (2013) reported almost similar tuber length and tuber diameter as the present study.

Harvest index was also highly significantly varied among tested sweet potato genotypes. Harvest index ranged from 0.20 to 0.72 ; the highest was found on the purplefleshed $F_{1}$ clone UNC2016.KDL/NPL.02 while the lowest was on the orange-fleshed $F_{1}$ clone UNC2016.NPL/KDL.02. The high harvest index of UNC2016.KDL/NPL.02 indicates its efficient use of the growing resource for tuber growth and development. Interestingly, this results revealed that the highest and the lowest harvest index were observed in the clones derived from the same parental genotypes, i.e., Kidal (KDL) and NPL-01 but the direction of the cross dictated their harvest index performance, indicating that maternal effect probably influences the harvest index of these $F_{1}$ reciprocal hybrids. Since harvest index is a function of two complex traits (Bhagsari and Ashley 1990; Júnior et al. 2018), i.e., the dry matter contents of the biological (vegetative) yield and yield; thus, it is hard to explain the existence of maternal effect in this case without having detailed genetic information on these two complex traits. Harvest index in sweet potato had been reported to be positively correlated with root dry matter content (Bhagsari and Ashley 1990) but Mbusa et al. (2018) reported no correlation between the two variables. This implies that correlation between these two variables in sweet potato is dependent on the genotypes used. Should there is positive correlation between harvest index and root dry matter content, then the differential harvest index between $F_{1}$ reciprocal hybrids may have been contributed by differences in their root dry matter content, which may be dictated by their parental clones. Maternal effect on sweet potato root dry matter content had been observed by earlier workers (Oduro 2013; Baafi et al. 2016). Lin et al. (2007) also reported maternal effect on shoot weight and root weight of sweet potato. Thus, if maternal effect presents in any reciprocal crosses of parental clones, it is necessary for breeders to pay attention for the direction of the crosses. Parental clones having superior maternal effect on important traits need to be used as female parents in hybridization.

The harvest index range of the present study closely resembled that reported by Rahajeng and Rahayuningsih (2017b) in OFSP grown in two locations in East Java, Indonesia. In contrast to this study, Mbusa et al. (2018) observed a much narrow range of harvest index (0.4-0.51) of Kenyan OFSP varieties. The wider range of harvest index observed in this study can serve as a genetic basis for the selection of sweet potato for both tuber yield as well as for fodder purposes.

Tuber yield was measured as fresh tuber weight plot $^{-1}$ $\left(4.2 \mathrm{~m}^{2}\right.$ ), which then converted into tuber yield ha $\mathrm{ha}^{-1}$ (Table 4). Fresh tuber yield varied considerably among the twenty sweet potato genotypes ranging from $4.80 \mathrm{~kg} \mathrm{plot}^{-1}(8.0 \mathrm{t}$ $\left.\mathrm{ha}^{-1}\right)$ to $26.03 \mathrm{~kg} \mathrm{plot}^{-1}\left(43.38 \mathrm{t} \mathrm{ha}^{-1}\right)$. The orange-fleshed $\mathrm{F}_{1}$ genotype UNC2016.JPV/KDL.11 produced the highest fresh tuber yield, consistent with its performance in tuber number plant $^{-1}$, which was also the highest among the tested clones. The high fresh tuber yield is shown by UNC2016.JPV/KDL.11 is supported by its highest performance in tuber number per plant, and its moderate performance in tuber length and tuber diameter. The study finding is in line with previous study results that tuber yield is positively correlated with tuber number per plant, tuber length and tuber diameter (Sasmal et al. 2015; Rahajeng and Rahayuningsih 2017b; Mbusa et al. 2018). Positive correlation between tuber yield and tuber yield component traits (tuber number per plant, tuber length and tuber diameter ) implies a linear relationship between them, where tuber yield will increase or decline along with the increase or the decline of the three traits. In addition to its good performances in tuber yield component traits, the genotype UNC2016.JPV/KDL.11 also performed the best in growth variables such as number of leaves per plant, which ultimately support optimum photosynthesis process for maximum tuber growth and development (Bhagsari and Ashley 1990).

Seven $F_{1}$ populations (five orange-fleshed and two purple-fleshed genotypes) produced an average tuber yield of $>25 \mathrm{t} \mathrm{ha}^{-1}$, much higher than the check varieties (Antin1, Antin-2, Beat-1, Beta-2) (Table 4). Tuber yields of the present orange-fleshed genotypes were much higher than those of orange-fleshed sweet potato evaluated in Blitar (4.2-21.6 t ha-1) and Mojokerto (2.1-30.9 t ha-1) (Rahajeng and Rahayuningsih 2017b) and ILETRI germplasm collection (0.48-25.84 t ha-1 (Rahajeng and Rahayuningsih 2017a). Saitama et al. (2017) reported tuber yield of several Indonesian sweet potato (yellow, orange and purplefleshed) varieties ranging between 8.9-44.8 $\mathrm{t} \mathrm{ha}^{-1}$. Meanwhile, the report on tuber yield of purple-fleshed sweet potato in Indonesia is limited. The high tuber yield exhibited by the seven $F_{1}$ sweet potato genotypes evaluated in this study highlighted their potency as promising clones. 
Table 4. Tuber number per plant, tuber length, tuber diameter, harvest index, and fresh tuber yield plot ${ }^{-1}$ of the sweet potato genotypes evaluated

\begin{tabular}{|c|c|c|c|c|c|c|}
\hline Sweet potato genotype & $\begin{array}{c}\text { Tuber } \\
\text { number per } \\
\text { plant }\end{array}$ & $\begin{array}{l}\text { Tuber length } \\
\text { (cm) }\end{array}$ & $\begin{array}{l}\text { Tuber } \\
\text { diameter } \\
\text { (cm) }\end{array}$ & $\begin{array}{c}\text { Harvest index } \\
(\%)\end{array}$ & $\begin{array}{l}\text { Marketable tuber } \\
\text { yield plot }^{-1}(\mathrm{~kg})\end{array}$ & $\begin{array}{c}\text { Marketable } \\
\text { tuber yield ha- } \\
\text { (t) }\end{array}$ \\
\hline UNC2016.CIL/JPV.01 & 3.00 abcd & $12.96 \mathrm{a}$ & 4.95 bcd & $0.54 \mathrm{ef}$ & 8.01 ef & $19.08 \mathrm{ef}$ \\
\hline UNC2016.CIL/JPV.02 & 3.50 abcde & $13.38 \mathrm{a}$ & 5.16 bcd & $0.29 \mathrm{~b}$ & $10.08 \mathrm{~g}$ & $24.00 \mathrm{~g}$ \\
\hline UNC2016.CIL/JPV.04 & $2.00 \mathrm{ab}$ & $21.85 \mathrm{e}$ & $3.00 \mathrm{a}$ & 0.38 cde & $3.36 \mathrm{a}$ & $8.00 \mathrm{a}$ \\
\hline UNC2016.CIL/JPV.05 & $2.50 \mathrm{abc}$ & $19.95 \mathrm{de}$ & $4.50 \mathrm{abcd}$ & $0.40 \mathrm{~cd}$ & $9.69 \mathrm{fg}$ & $23.08 \mathrm{fg}$ \\
\hline UNC2016.KDL/NPL.02 & 3.00 abcd & $13.68 \mathrm{ab}$ & $3.98 \mathrm{ab}$ & $0.72 \mathrm{~h}$ & $7.11 \mathrm{~cd}$ & $16.92 \mathrm{~cd}$ \\
\hline UNC2016.JPV/KDL.08 & 3.00 abcd & $16.91 \mathrm{abcd}$ & 5.73 bcde & $0.65 \mathrm{fg}$ & $15.77 \mathrm{j}$ & $37.54 \mathrm{j}$ \\
\hline UNC2016.JPV/KDL.11 & $5.50 \mathrm{e}^{4}$ & $14.95 \mathrm{abc}$ & $5.25 \mathrm{bcd}$ & $0.70 \mathrm{~h}$ & $18.22 \mathrm{kl}$ & $43.38 \mathrm{kl}$ \\
\hline UNC2016.JPV/KDL.02 & 4.50 cde & $18.20 \mathrm{cde}$ & $4.40 \mathrm{abcd}$ & $0.68 \mathrm{gh}$ & $12.66 \mathrm{gh}$ & $30.15 \mathrm{gh}$ \\
\hline UNC2016.NPL/JPV//KDL.02 & $2.50 \mathrm{abc}$ & $14.17 \mathrm{abc}$ & $6.02 \mathrm{de}$ & $0.43 \mathrm{~cd}$ & $9.18 \mathrm{efg}$ & $21.85 \mathrm{efg}$ \\
\hline UNC2016.NPL/KDL.02 & $1.50 \mathrm{a}$ & $16.57 \mathrm{abcd}$ & $5.24 \mathrm{bcd}$ & $0.20 \mathrm{a}$ & $3.88 \mathrm{ab}$ & $9.23 \mathrm{ab}$ \\
\hline UNC2016.KDL/NPL.01 & $5.00 \mathrm{de}$ & $16.76 \mathrm{abcd}$ & 4.38 abcd & $0.30 \mathrm{~b}$ & $12.79 \mathrm{hi}$ & $30.46 \mathrm{hi}$ \\
\hline UNC2016.NPL/PSOL.16 & $4.00 \mathrm{bcde}$ & $17.65 \mathrm{bcd}$ & $6.05 \mathrm{de}$ & $0.46 \mathrm{~d}$ & $14.47 \mathrm{hij}$ & 34.46 hij \\
\hline UNC2016.NPL/SBD.04.1 & $3.00 \mathrm{abcd}$ & $16.59 \mathrm{abcd}$ & $7.21 \mathrm{e}$ & $0.37 \mathrm{bc}$ & $17.06 \mathrm{jk}$ & $40.62 \mathrm{jk}$ \\
\hline UNC2016.JPV/KDL//NPL.04 & $3.00 \mathrm{abcd}$ & $14.18 \mathrm{abc}$ & $4.03 \mathrm{abc}$ & $0.41 \mathrm{def}$ & $3.75 \mathrm{ab}$ & $8.92 \mathrm{ab}$ \\
\hline UNC2016.PSOL/NPL.15 & $2.50 \mathrm{abc}$ & $12.75 \mathrm{a}$ & $7.25 \mathrm{e}$ & 0.39 cde & 8.79 efg & $20.92 \mathrm{efg}$ \\
\hline UNC2016.KDL/V1-CIL.01 & $2.75 \mathrm{abc}$ & $18.26 \mathrm{cde}$ & 5.50 bcde & 0.45 cdef & $15.12 \mathrm{ij}$ & $36.00 \mathrm{ij}$ \\
\hline ANTIN-1 & $1.50 \mathrm{a}$ & $15.63 \mathrm{abc}$ & $5.25 \mathrm{bcd}$ & $0.31 \mathrm{bc}$ & $5.43 \mathrm{bc}$ & $12.92 \mathrm{bc}$ \\
\hline ANTIN-2 & $1.50 \mathrm{a}$ & $13.55 \mathrm{ab}$ & $4.00 \mathrm{ab}$ & $0.42 \mathrm{~cd}$ & $6.85 \mathrm{~cd}$ & $16.31 \mathrm{c}$ \\
\hline BETA-1 & 3.50 abcde & $14.18 \mathrm{abc}$ & $5.91 \mathrm{cde}$ & $0.48 \mathrm{def}$ & $7.75 \mathrm{de}$ & $18.46 \mathrm{de}$ \\
\hline BETA-2 & $1.50 \mathrm{a}$ & $14.13 \mathrm{abc}$ & 5.54 bcde & $0.32 \mathrm{bc}$ & $4.14 \mathrm{ab}$ & $9.85 a b$ \\
\hline Mean & 2.96 & 15.81 & 5.17 & 0.47 & 9.71 & 23.11 \\
\hline F-value (calculated) & $3.57^{* *}$ & $3.98^{* *}$ & $3.72^{* *}$ & $20.55^{* *}$ & $66.22^{* *}$ & \\
\hline Coefficient of variation & 18.50 & 12.18 & 15.87 & 12.44 & 8.37 & \\
\hline
\end{tabular}

Note: ${ }^{*}$ highly significant $(\mathrm{P}<01),{ }^{*}$ significant $(\mathrm{P}<0.05)$. Numbers within the same column followed by the same letter $(\mathrm{s})$ are not significantly different at 0.05 DMRT

It is interesting to observe that tuber yields of the check varieties included in the present study were lower than $20 \mathrm{t}$ $\mathrm{ha}^{-1}$. Tuber yields of the check varieties Beta-1 (18.46 tha$\left.{ }^{1}\right)$ and Antin-2 $\left(16.31 \mathrm{t} \mathrm{ha}^{-1}\right)$ were only about $60 \%$ of their average yields presented in the varietal description. Tuber yields of other check varieties Antin-1 (12.92 t ha- $\left.{ }^{-1}\right)$ and Beta-2 $\left(9.85 \mathrm{t} \mathrm{ha}^{-1}\right)$ were only around, respectively, $40 \%$ and $25 \%$ of their potential yield. Saitama et al. (2017) observed the tuber yield of check varieties Antin-1, Antin-2 and Beta-1 of, respectively, 8.86, 11.96 and $33.84 \mathrm{t} \mathrm{ha}^{-1}$ during dry season in East Jawa, which significantly differed from those of the present study, indicating that yield performance of these varieties varied considerably according to the variation in the environmental conditions. Thus, tuber yield of sweet potato is determined by an interaction between genetic and environmental factors as reported in the previous studies (Yusuf et al. 2008; Osiru et al. 2009; Moussa et al. 2011; Haldavanekar et al. 2011; Mau et al. 2013; Rahajeng and Rahayuningsih 2017).

\section{Drought tolerance level}

Drought tolerance levels of the genotypes were determined based on their yield performances in no stress and water-stressed conditions. Tuber yield plot $^{-1}$ of the genotypes was converted to yield $\mathrm{ha}^{-1}$ before being subjected to drought tolerance assessment and calculated the drought tolerance indices (Table 5). Tuber yields in no stress/normal condition differed substantially from those in water-stressed condition. A mean tuber yield range of 9.33$42.83 \mathrm{t} \mathrm{ha}^{-1}$ was observed in no water stress condition while that in water-stressed condition ranged between 1.08-15.90 $\mathrm{t} \mathrm{ha}{ }^{-1}$. The highest mean yield in no stress and stressed conditions was observed in, respectively, UNC2016.JPV/KDL.11 (orange-fleshed) and UNC2016.Cil/JPV.01 (purple-fleshed) while the lowest mean yields in no stress and stressed conditions, was observed in Beta-2 and Beta-1, respectively. Substantial mean yield differences among genotypes under different irrigation levels indicate the presence of interaction effect of genotype by environment, where the expression of genes controlling tuber yield trait depends significantly on the genotype and water level condition. There was a significant difference in the overall mean tuber yield of all genotypes under no water stress $\left(23.42 \mathrm{tha}^{-1}\right)$ and water-stressed (7.08 $\left.\mathrm{t} \mathrm{ha}^{-1}\right)$ conditions, which indicates a very high stress intensity ((1-(Ys/Yp)) (Bennani et al. 2017) of 0.70 (within the range of 0.0-1.0). Mau et al. (2011) had also observed a dramatic difference of mean tuber yield of local sweet potato from NTT Province under normal and waterstressed conditions of $12.6 \mathrm{t} \mathrm{ha}^{-1}$ and $6.0 \mathrm{t} \mathrm{ha}^{-1}$, respectively, with a stress intensity of about 0.5 . These differences did occur, presumably, due to both different responses of the genotypes evaluated as well as the different drought stress treatment applied. High-stress intensity imposed in the present study may have selected the most drought tolerant genotypes, but other potential genotypes may have been discarded. Moderate stress intensities $(0.3-0.5)$ are considered to be more suitable for selection of drought-tolerant crop genotypes (Ali and ElSadek 2016). 
Table 5. Fresh tuber yield $\left(\mathrm{t} \mathrm{ha}^{-1}\right)$ under no stress and water-stressed conditions and drought tolerance indices of tested sweet potato genotypes

\begin{tabular}{|c|c|c|c|c|c|c|c|c|c|c|c|}
\hline \multirow{2}{*}{ Sweet potato genotype } & \multicolumn{11}{|c|}{ Drought tolerance indices } \\
\hline & Yp & Ys & MP & STI & GMP & SSI & MRP & HARM & YSI & REI & SNPI \\
\hline UNC2016.CIL/JPV.01 & 20.67 & 15.90 & 18.00 & 0.64 & 17.88 & 0.30 & 3.15 & 17.75 & 0.79 & 2.02 & 35.20 \\
\hline UNC2016.CIL/JPV.02 & 23.67 & 7.80 & 15.45 & 0.37 & 13.42 & 0.96 & 2.15 & 11.66 & 0.34 & 1.17 & 14.16 \\
\hline UNC2016.CIL/JPV.04 & 9.00 & 2.70 & 5.70 & 0.05 & 4.84 & 1.00 & 0.78 & 4.12 & 0.31 & 0.15 & 4.94 \\
\hline UNC2016.CIL/JPV.05 & 23.50 & 3.30 & 13.05 & 0.15 & 8.65 & 1.24 & 1.49 & 5.75 & 0.15 & 0.48 & 6.92 \\
\hline UNC2016.KDL/NPL.02 & 27.00 & 5.70 & 11.10 & 0.19 & 9.70 & 0.95 & 1.54 & 8.47 & 0.35 & 0.59 & 10.33 \\
\hline UNC2016.JPV/KDL.08 & 38.17 & 12.00 & 24.60 & 0.90 & 21.13 & 0.99 & 3.37 & 18.15 & 0.32 & 2.84 & 21.87 \\
\hline UNC2016.JPV/KDL.11 & 42.83 & 10.20 & 25.95 & 0.87 & 20.62 & 1.10 & 3.32 & 16.39 & 0.25 & 2.75 & 19.26 \\
\hline UNC2016.JPV/KDL.02 & 29.67 & 12.60 & 20.70 & 0.73 & 19.02 & 0.82 & 3.06 & 17.49 & 0.44 & 2.29 & 22.76 \\
\hline UNC2016.NPL/JPV//KDL.02 & 21.33 & 6.00 & 13.35 & 0.25 & 11.14 & 1.03 & 1.78 & 9.30 & 0.29 & 0.79 & 11.06 \\
\hline UNC2016.NPL/KDL.02 & 9.00 & 3.00 & 5.85 & 0.05 & 5.09 & 0.96 & 0.81 & 4.44 & 0.34 & 0.16 & 5.46 \\
\hline UNC2016.KDL/NPL.01 & 29.83 & 9.90 & 19.50 & 0.59 & 16.96 & 0.96 & 2.69 & 14.76 & 0.34 & 1.84 & 17.97 \\
\hline UNC2016.NPL/PSOL.16 & 34.83 & 15.00 & 24.45 & 1.03 & 22.52 & 0.81 & 3.65 & 20.75 & 0.44 & 3.24 & 27.11 \\
\hline UNC2016.NPL/SBD.04.1 & 38.50 & 6.00 & 21.75 & 0.44 & 14.77 & 1.21 & 2.53 & 10.19 & 0.17 & 1.39 & 12.26 \\
\hline UNC2016.JPV/KDL//NPL.04 & 8.67 & 1.50 & 4.95 & 0.03 & 3.55 & 1.20 & 0.59 & 2.54 & 0.18 & 0.08 & 3.00 \\
\hline UNC2016.PSOL/NPL.15 & 20.67 & 7.50 & 13.80 & 0.30 & 12.24 & 0.92 & 1.95 & 10.87 & 0.37 & 0.95 & 13.58 \\
\hline UNC2016.KDL/V1-CIL.01 & 35.83 & 16.80 & 25.80 & 1.16 & 24.04 & 0.75 & 3.92 & 22.43 & 0.49 & 3.66 & 30.97 \\
\hline ANTIN-1 & 12.67 & 1.80 & 7.05 & 0.04 & 4.70 & 1.24 & 0.81 & 3.14 & 0.15 & 0.14 & 3.77 \\
\hline ANTIN-2 & 15.67 & 1.05 & 8.18 & 0.03 & 4.00 & 1.35 & 0.84 & 1.96 & 0.07 & 0.10 & 2.68 \\
\hline BETA-1 & 17.50 & 1.08 & 9.09 & 0.04 & 4.27 & 1.36 & 0.92 & 2.03 & 0.07 & 0.12 & 2.82 \\
\hline BETA-2 & 9.33 & 1.80 & 5.40 & 0.03 & 4.02 & 1.17 & 0.65 & 2.99 & 0.19 & 0.11 & 3.52 \\
\hline Mean & 23.42 & 7.08 & 14.69 & 0.39 & 12.13 & 1.02 & 2.00 & 10.26 & 0.30 & 1.24 & 13.48 \\
\hline
\end{tabular}

Note: $\mathrm{Yp}=$ yield under no stress condition, $\mathrm{Ys}=$ yield under water-stressed condition, MP = Mean yield under both no stress and waterstressed conditions, STI=stress tolerance index, SSI=stress susceptibility index, GMP=geometric mean performance, MRP=mean relative performance, HARM=harmonic yield, YSI=yield stress index, REI=relative expression index, SNPI= Stress non-stress production index. Shaded area indicates that the genotype was selected as drought-tolerant based on the drought index and tuber yield in no stress (Yp) an stressed (Ys) conditions.

The sweet potato genotypes varied greatly in their drought tolerance indices (Table 5). Drought tolerance index MP selected seven genotypes (Table 6) that produced $\geq 18 \mathrm{t} \mathrm{ha}^{-1}$ fresh tuber yields under no stress and stressed conditions, which is above the current national average tuber yield of $16 \mathrm{t} \mathrm{ha}^{-1}$ (BPS 2015). The drought tolerance index STI was used to select for drought tolerant and high yielding genotypes under no stress condition, indicated by the STI values of $\geq 1.0$ (Fischer and Maurer 1978; Fernandez 1992). Based on the STI, only two genotypes were classified as drought tolerant, i.e., UNC2016.NPL/PSOL.16 and UNC2016.KDL/V1-CIL.01.

GMP index selected six genotypes (UNC2016.CIL/JPV.01, UNC2016.JPV/KDL.08, UNC2016.JPV/KDL.11, UNC2016.JPV/KDL.02, UNC2016.NPL/PSOL.16, UNC2016.KDL/V1-CIL.01) based on their geometric mean yield performance of above the recent national mean tuber yield (BPS 2015). In contrast to STI, SSI selected drought-tolerant genotypes with a stable yield between no stress and stressed conditions indicated by an SSI value of $\leq 0.5$ (Fernandez 1992; Sio-Se et al. 2006). Based on this index, only one genotype was classified as drought tolerant, i.e., UNC2016.CIL/JPV.01. These genotypes were selected as it could produce somewhat stable tuber yield of about $20 \mathrm{tha}$ ${ }^{1}$ in no stress condition and about $16 \mathrm{t} \mathrm{ha}^{-1}$ in stressed condition. Similar to SSI, YSI also selected only one genotype (UNC2016.CIL/JPV.01) based on its stable tuber yield performance under no stress and water-stressed conditions. Genotypes having YSI index of $\geq 0.5$ is considered to be drought tolerant.

In contrast to STI, SSI, and YSI, which have a specific standard range of index value to select for drought-tolerant genotypes, the drought indices MRP, HARM, REI dan SNPI (Farshadfar and Sutka 2002; Moosavi et al. 2008; Ali et al. 2013) provide no such range of index value for the preferred genotypes selection. The higher the values of these indices, the better; thus, certain selection intensity needs to be set up to select the most desirable/drought tolerant genotypes based on these indices. If a $30 \%$ selection intensity is used, then six genotypes were selected by each of these four indices as the most drought-tolerant genotypes. The selected genotypes were similar for all the four indices, i.e., UNC2016.CIL/JPV.01, UNC2016.JPV/KDL.08, $\quad$ UNC2016.JPV/KDL.11, UNC2016.JPV/KDL.02, UNC2016.NPL/PSOL.16, and UNC2016.KDL/V1-CIL.01. Interestingly, these six genotypes were also classified as drought-tolerant by drought indices MP and GMP (Tabel 5). These results indicate that these drought indices can be used interchangeably to select for drought-tolerant sweet potato genotypes. 
Table 6. Sweet potato genotypes selected as drought-tolerant genotypes based on drought tolerance indices employed

\begin{tabular}{|c|c|c|c|}
\hline $\begin{array}{l}\text { Drought tolerance } \\
\text { indices }\end{array}$ & Selected genotypes & & \\
\hline MP & $\begin{array}{l}\text { UNC2016.CIL/JPV.01, } \quad \text { UNC2016.JPV/KDL.08, } \\
\text { UNC2016.NPL/PSOL.16, UNC2016.NPL/SBD.04.1, }\end{array}$ & $\begin{array}{l}\text { UNC2016.JPV/KDL.11, } \\
\text { C2016.KDL/V1-CIL.01 }\end{array}$ & UNC2016.JPV/KDL.02, \\
\hline STI & UNC2016.NPL/PSOL.16, UNC2016.KDL/V1-CIL.01 & & \\
\hline GMP & $\begin{array}{l}\text { UNC2016.CIL/JPV.01, } \quad \text { UNC2016.JPV/KDL.08, } \\
\text { UNC2016.NPL/PSOL.16, UNC2016.KDL/V1-CIL.01 }\end{array}$ & UNC2016.JPV/KDL.11, & UNC2016.JPV/KDL.02, \\
\hline SSI & UNC2016.CIL/JPV.01 & & \\
\hline MRP & $\begin{array}{l}\text { UNC2016.CIL/JPV.01, } \quad \text { UNC2016.JPV/KDL.08, } \\
\text { UNC2016.NPL/PSOL.16, UNC2016.KDL/V1-CIL.01 }\end{array}$ & UNC2016.JPV/KDL.11, & UNC2016.JPV/KDL.02, \\
\hline HARM & $\begin{array}{l}\text { UNC2016.CIL/JPV.01, } \quad \text { UNC2016.JPV/KDL.08, } \\
\text { UNC2016.NPL/PSOL.16, UNC2016.KDL/V1-CIL.01 }\end{array}$ & UNC2016.JPV/KDL.11, & UNC2016.JPV/KDL.02, \\
\hline YSI & UNC2016.CIL/JPV.01 & & \\
\hline REI & $\begin{array}{l}\text { UNC2016.CIL/JPV.01, } \quad \text { UNC2016.JPV/KDL.08, } \\
\text { UNC2016.NPL/PSOL.16, UNC2016.KDL/V1-CIL.01 }\end{array}$ & UNC2016.JPV/KDL.11, & UNC2016.JPV/KDL.02, \\
\hline SNIP & $\begin{array}{l}\text { UNC2016.CIL/JPV.01, UNC2016.JPV/KDL.08, } \\
\text { UNC2016.NPL/PSOL.16, UNC2016.KDL/V1-CIL.01 }\end{array}$ & UNC2016.JPV/KDL.11, & UNC2016.JPV/KDL.02, \\
\hline
\end{tabular}

Only one genotype (UNC2016.Cil/JPV.01) was classified as drought-tolerant based on all nine drought tolerance indices employed (Table 6). Further, one genotype (UNC2016.NPL/PSOL.16) was classified as drought-tolerant based on seven indices (except SSI dan YSI), and four genotypes (UNC2016.JPV/KDL.08, UNC2016.JPV/KDL.11, UNC2016.JPV/KDL.02, and UNC2016.KDL/V1-CIL.01) were classified as droughttolerant based on six drought indices (except STI, SSI, and YSI). These five genotypes were not selected by SSI and YSI due to their high yield loss of $>50 \%$ in the stressed condition. The genotype UNC2016.NPL/SBD.04.1 was only selected by MP. Thus; the results show that six genotypes, i.e., UNC2016.CIL/JPV.01, UNC2016.JPV/KDL.08, UNC2016.JPV/KDL.11, UNC2016.JPV/KDL.02， UNC2016.NPL/PSOL.16, and UNC2016.KDL/V1-CIL.01 were classified as droughttolerant genotypes because they were selected by all or most of the drought indices employed.

Most of the drought tolerance indices used to select the above drought tolerant sweet potato genotypes have been shown to be effective in selecting drought-tolerant genotypes of various crops (Fischer and Maurer 1978; Bidinger et al. 1978; Farshadfar and Sutka 2002; Moosavi et al. 2008; Mau et al. 2011; Ali et al. 2013; Mau et al. 2014; Mau et al. 2019). The six selected sweet potato genotypes also exhibited high yielding performance $(\geq 20 \mathrm{t}$ $\mathrm{ha}^{-1}$ tuber yield) under no stress condition and moderate yielding performance $\left(\geq 10 \mathrm{t} \mathrm{ha}^{-1}\right)$ under water-stressed condition. Yields under no stress (Yp) and stressed (Ys) conditions were found to be positively correlated with drought tolerance (Moosavi et al. 2008; Farshadfar and Elyasi 2012; Ali et al. 2013; Mau et al. 2019). Thus, the six selected sweet potato genotypes are not only drought tolerant but also high yielding. These genotypes are, therefore, need to be further subjected to multi- environmental trial and potentially be proposed for superior varietal release.

In conclusion, the present study revealed substantial differences among twenty sweet potato genotypes in all the observed agronomic performance variables. Two of the tested genotypes were short maturing with only about 90 days to harvesting (UNC2016.Cil/JPV.01 and UNC2016.Cil/JPV.05). Tuber yields also varied greatly among genotypes with the highest was recorded in the orange-fleshed $\mathrm{F}_{1}$ clone UNC2016.JPV/KDL.11 (43.38 t $\left.\mathrm{ha}^{-1}\right)$. The highest tuber yield in purple-fleshed clones was observed in UNC2016.NPL/PSOL.16 (34.46 t ha-1). Mean tuber yield under no stress condition was much higher than that of water-stressed condition. Six genotypes (UNC2016.CIL/JPV.01, UNC2016.JPV/KDL.08, UNC2016.JPV/KDL.11, UNC2016.JPV/KDL.02, UNC2016.NPL/PSOL.16, UNC2016.KDL/V1-CIL.01) were classified as drought tolerant, high yielding under both no stress and water-stressed conditions. These genotypes are considered as promising clones that need to be further evaluated in multi environments before being proposed as candidates for varietal release.

\section{ACKNOWLEDGEMENTS}

We are very thankful to the Directorate of Research and Community Services (DRPM) of Indonesian Ministry of Research, Technology and Higher Education for supporting this research through Penelitian Strategis Nasional Institusi research scheme, the financial year 2018 (Contract Number: 114/UN15.19/LT/2018). Special thanks are also addressed to Bonifasius Edo, Fransiskus Toliredo, and Even Bria for the great assistance they provided during the research in the field. 


\section{REFERENCES}

Ali MB, El-Sadek A. 2016. Evaluation of drought tolerance indices for wheat (Triticum aestivum L.) under irrigated and rainfed conditions. Commun Biometry Crop Sci 11 (1): 77-89.

Baafi E, Gracen VE, Manu-Aduening J, Blay ET, Ofori K, Carey EE. 2016. Genetic control of dry matter, starch and sugar content in sweet potato. Acta Agric Scand B Soil Plant Sci 1-9. DOI 10.1080/09064710.2016.1225813.

BALITKABI 2016. Deskripsi varietas unggul ubi jalar 1977-2016. Balai Penelitian Kacang-Kacangan dan Umbi-Umbian. Malang, Jawa Timur. [Indonesian].

Bhagsari AS, Ashley DA. 1990. Relationship of photosynthesis and harvest index to sweet potato yield. J Amer Soc Hort Sci 115 (2): 288-293.

BPS 2015. Poduktivitas Ubi Jalar Menurut Provinsi 1993-2015. Badan Pusat Statistik, Jakarta. Available from: https://www.bps.go.id/dynamictable/2015/09/09/884/produktivitasubi-jalar-menurut-provinsi-kuintal-ha-1993-2015.html. [Indonesian]

Bennani S, Nsarellah N, Jlibene M, Tadesse W, Birouk A, Ouabbou H (2017) Efficiency of drought indices under different severities for bread wheat selection. Aust J Crop Sci 11 (04): 395-405.

Bidinger FR, Mahalakshmi V, Rao GDP. 1987. Assessment of drought resistance in pearl millet (Pennisetum americanum (L) Leeke). I. Factors affecting yields under stress. Aust J Agr Sci 38: 37-48.

Brouwer G, Herbloem M. 1986. Irrigation water needs. Irrigation water management Training Manual No. 3 FAO Rome Italy. 58.

Farshadfar E, Sutka J. 2002. Multivariate analysis of drought tolerance in wheat substitution lines. Cereal Res Commun 31: 33-40.

Farshadfar E, Elyasi P. 2012. Screening quantitative indicators of drought tolerance in bread wheat (T. aestivum) landraces. Eur J Exp Biol 2 (3): $577-584$.

Fernandez GCJ. 1992. Effective selection criteria for assessing plant stress tolerance. In: Kuo CG (ed) Adaptation of food crops to temperature and water stress. Proceeding of an Int Symp AVRDC-Inst of Botany, Taiwan. 257-270.

Fischer RA, Maurer R. 1978. Drought resistance in spring wheat cultivar: I. Grain yield response. Aust J Agric Res 29: 897-912.

Ginting E, Yulifianti R, Jusuf M, Mejaya MJ. 2014. Identifikasi sifat fisik, kimia, dan sensoris klon-klon harapan ubijalar kaya antosianin. Jurnal Penelitian Tanaman Pangan 34 (1): 69-78. [Indonesian]

Haldavanekar PC, Bhave SG, Kahandekar RG, Kadam SG, Sawant SS. 2011. Stability analysis in sweet potato (Ipomea batatas L.) Karnataka J Agric Sci 24 (3): 358-361.

Husna NE, Novita M, Rohaya S. 2013. Kandungan antosianin dan aktivitas antioksidan ubi jalar ungu segar dan produk olahannya. Agritech 33 (3): 296-302. [Indonesian]

Jang YP, Zhou J, Nakanishi K, Sparrow JR. 2005. Anthocyanins protect againts $\mathrm{A} 2 \mathrm{E}$ photooxidation and membrane permeabilization in retinal pigment epithelial cells. Photochem Photobiol 81:529-536.

Ji H, Zhang HX, Li HT, Li YC. 2015. Analysis on the nutrition composition and antioxidant activity of different types of sweet potato cultivars. Food Nutr Sci 6:161-167.

Júnior RAP, Patto MA, Martins ES, Abreu AFB. 2018. Inheritance of harvest index in common bean. Crop Crop Breed Appl Biot 18: 252258. Available from: http://dx.doi.org/10.1590/1984$70332018 v 18$ n3a38.

Kobayashi M, Oki T, Masuda M, Nagai S, Fukui K, Matsugano K, Suda I. 2005. Hypotensive effect of anthocyanin-rich extract from purplefleshed sweet potato cultivar 'Ayamurasaki' in spontaneously hypertensive rats. J Japanese Society Food Sci Technol 52:41 -44.

Kurata R, Adachi M, Yamakawa O, Yoshimoto M. 2007. Growth suppression of human cancer cells by polyphenolics from Sweet potato (Ipomoea batatas L.) leaves. J Agric Food Chem 55: 185-190. http://dx.doi.org/10.1021/jf0620259

Lim S, Xu J, Kim J, Chen TY, Su X, Standard J, Carey E, Griffin J, Herndon B, Katz B, Tomich J, Wang W. 2013. Role of anthocyaninenriched purple-fleshed sweet potato p40 in colorectal cancer prevention. Mol Nutr Food Res 57 (11): 1908-17.

Lin KH, Lai YC, Chang KY, Chen YF, Hwang SY, Lo HF. 2007. Improving breeding efficiency for quality and yield of Sweet potato. Bot Stud. 48:283-292.

Mau YS, Ndiwa AS, Markus JER, Oematan SS. 2019. Drought Tolerance indices for selection of drought-tolerant, high yielding upland rice genotypes. Aust J Crop Sci 10 (3): 170-178. DOI: 10.21475/ajcs.19.13.01.p17.

Mau YS, Ndiwa ASS, Adwita Arsa IGB, Markus JER. 2016. Evaluasi keserasian silang ubi jalar lokal NTT, varietas unggul nasional dan varietas introduksi untuk merakit klon-klon unggul yang memiliki daya hasil tinggi, kualitas hasil baik serta tahan cekaman tress dan abiotik. Laporan Penelitian Produk Terapan. Universitas Nusa Cendana, Kupang. [Indonesian]

Mau YS, Ndiwa ASS, Adwita Arsa IGB, Oematan SS. 2013. Growth and yield stability of sweet potato clones across four locations in East Nusa Tenggara. Agrivita 35 (1): 95-102.

Mau YS, Ndiwa ASS, Adwita Arsa IGB. 2011. Tingkat ketahanan beberapa klon ubi jalar unggul asal Nusa Tenggara Timur terhadap hama lanas (Cylas formicarius Fab.). JHPT Tropika 11 (2): 139-146. [Indonesian]

Mau YS, Ndiwa ASS, Arsa IGBA. 2014. Drought tolerance of local rote and check varieties of groundnut (Arachis hypogaea L.) during dry season in two locations in East Nusa Tenggara. Agrivita 36 (3): 268-277.

Mau YS. 2011. Evaluation of drought tolerance level of sweet potato (Ipomoea batatas L.) germplasm from East Nusa Tenggara Province. In Nurbaity A, Subroto E, Setyowati EY, Stanica F, Bari IN, Wimmers K, Carsono N, Mulyani O, Lehmousloto P, Teng PS, Siswanto SY, Aleksic S (Eds.). Proceeding of International Conference on Sustainable Agriculture and Food Security: Challenges and Opportunities. 370-376.

Mau YS. 2018. Resistance response of fifteen sweet potato genotypes to scab disease (Sphaceloma batatas) in two growing sites in East Nusa Tenggara, Indonesia. Trop Drylands 2: 5-11.

Mbusa HK, Ngugi K, Olubayo FM, Kivuva BM, Muthomi JW, Nzuve FM. 2018. Agronomic performance of Kenyan orange-fleshed sweet potato varieties. J Plant Stud 7 (2): 11-18.

Moosavi SS, Samadi YB, Naghavi MR, Zali AA, Dashti H, Pourshahbazi A. 2008. Introduction of new indices to identify relative drought tolerance and resistance in wheat genotypes. Desert 12: 165-178.

Moussa SAM, El-Aal HAA, El-Fadl NIA. 2011. Stability Study of sweet potato yield and its component characters under different environments by joint regression analysis. JHSOP 3 (1): 43-54.

Odun V. 2013. Genetic control of sugars, cry matter, and beta-carotene in sweet potato (Ipomoea batatas [L.] Lam). [Thesis] University of Ghana, Accra.

Oki T, Nagai S, Yoshinaga M, Nishiba Y, Suda I. 2006. Contribution of Bcarotene to radical scavenging capacity varies among orange-fleshed sweet potato cultivars. Food Sci Technol Res 12 (2): 156-160.

Osiru M, Olanya OM, Adipala E, Kapinga E, Lemaga B. 2009. Yield stability analysis of Ipomoea batatas L. cultivars in diverse environments. Aust J Crop Sci 3 (4): 213-220.

Rabah IO, Hou DX, Komine SI, Fuji M. 2004. Potential chemopreventive properties of extracts from baked sweet potato (Ipomoea batatas Lam. Cv. Koganesengan). J Agr Food Chem 23: 7152-7157.

Rahajeng W, Rahayuningsih S.A. 2017a. Agronomic performance, variance component, and diversity of sixty-two sweet potato $\begin{array}{lllll}\text { accessions. Biodiversitas } 18 & \text { (1): 95-100. DOI: }\end{array}$ 10.13057/biodiv/d180114

Rahajeng W, Rahayuningsih S.A. 2017b. Evaluation of orange-fleshed sweet potato genotypes for yield and yield contributing parameters in two environments. Nusantara Biosci 9 (3): 275-281. DOI: 10.13057/nusbiosci/n090306

Rahman MH, Alam Patwary MM, Barua H, Hossain M, Nahar S. 2013. Evaluation of orange-fleshed sweet potato (Ipomoea batatas L.) genotypes for higher yield and quality. The Agriculturists 11 (2): 2127.

Richardson KVA. 2009. Tuber quality and yield of eight sweet potato varieties evaluated during 2008. Gladstone Road Agricultural Centre Crop Research Report no. 2. Department of Agriculture Nassau, Bahamas.

Rose, Vasanthakaalam. 2011. Comparison of the nutrient composition of four sweet potato varieties cultivated in Rwanda. Am J Food Nutr 1 (1): $34-38$.

Saigusa K, Hashimoto N, Tsuda H, Yokoi S, Maruno M, Yoshimine T, Aoyagi M, Ohno K, Imoto I, Inazawa J. 2005. Overexpressed Skp2 within $5 \mathrm{p}$ amplification detected by array-based comparative genomic hybridization is associated with poor prognosis of glioblastomas. Cancer Sci 96: 676-683. 
Saitama A, Nugroho A, Widaryanto e. 2017. Yield response of ten varieties of sweet potato (Ipomoea batatas L.) cultivated on dryland in rainy season. J Degrade Min Land Manage 4 (4): 919-926. DOI:10.15243/jdmlm.2017.044.919.

Sasmal M, Mondal CK, Garain PK, Acharyya P. 2015. Evaluation of sweet potato (Ipomoea batatas (L.) Lam.) germplasm suitable for the coastal agroclimatic situation of Sundarbans, West Bengal. Inter J App Pure Sci Agric 1 (5): 49-57.

Sio-Se MA, Ahmadi A, Poustiniand K, Mohammadi V. 2006. Evaluation of drought resistance indices under various environmental conditions. Field Crop Res 98: 222-229.

Teow CC, Truon VD, McFeeters RF, Thompson RL, Pecota KV, Yencho GC. 2007. Antioxidant activities, phenolic and beta-carotene contents of sweet potato genotypes with varying flesh colors. Food Chem 103:829-838.

Wang YJ, Zheng YL, Lu J. 2010. Purple sweet potato color suppresses lipopolysaccharide-induced acute inflammatory response in mouse brain. Neurochem Int. 56 (3): 424-30.

Yusuf M, Rahayuningsih St A, Wahyuni TS, Restuono J. 2008. Adaptation and yield stability of promising sweet potato clones. Indonesian J Food Crop Res 27 (1): 37-41.

Zhang ZF, Fan S, Zheng YL. 2009. Purple sweet potato color attenuates oxidative stress and inflammatory response induced by d-galactose in mouse liver. Food Chem Toxicol 47 (2): 496-501. 